\title{
PARAMETRIC OPTIMISATION OF PULSED - TIG WELDING PROCESS IN BUTT JOINING OF 304L AUSTENITIC STAINLESS STEEL SHEETS
}

\author{
Dinesh Kumar.R ${ }^{1}$, Elangovan. $S^{2}$, Siva Shanmugam. $\mathbf{N}^{3}$ \\ ${ }^{1}$ PG Student, ME-Production Engineering, PSG College of Technology, Coimbatore, Tamil Nadu, India \\ ${ }^{2}$ Associate Professor, Production Engineering, PSG College of Technology, Coimbatore, Tamil Nadu, India \\ ${ }^{3}$ Assistant Professor, Mechanical Engineering, National Institute of Technology, Tiruchirappalli, Tamil Nadu, India
}

\begin{abstract}
Stainless steels are widely used in thermal power plant, pressure vessels and automobiles components due to their superior fracture toughness, good inter granular corrosion resistance and non-requirement of post process annealing. Heat affected zone decreases the strength of the weld hence Pulsed TIG welding process is carried out to reduce the heat affected zone. This inherent property of the material reduces crack growth at high pressure which leads to the increase in efficiency of the pressure vessels and automobile components, when operated at high pressure. This paper describes the optimization of process parameters like current, voltage, stand-off distance, pulse on time, pulse off time and weld speed, gas flow to improve weld quality. In this work Taguchi method is used to get the optimal parameters. In Taguchi method, L27 orthogonal array is used for experimentation. Further, the experimental values and the various settings of the process parameters are fed as input to Taguchi and hence the S/N ratio values are obtained. Weld speed and input current are found to be the most significant parameters. Finally, the strength of the weld is validated by tensile and bending test.
\end{abstract}

Keywords: Stainless Steel, Pulsed TIG welding, Inter-granular corrosion resistance, Fracture toughness, strength testing, Taguchi method.

\section{INTRODUCTION}

In today's scenario welding of thin sheets is being the challenging task in the field of Engineering. The major reason behind this is perfection, which is being the nominal factor considered during the joining process of sheets because, in such joining of plate, two pass and three pass welding cannot be carried out in thin sheets below $4 \mathrm{~mm}$, as under welding results in predominant reduction in strength and over weld results in formation of hole. Hence optimization of weld parameter plays a predominant role in joining of thin sheets. This research is to make the thin sheet welding easy and compatible by optimizing the process parameters. And in this paper, we have explained about the suitable parameters for butt joining on 304L Stainless Steel material of thickness $1.6 \mathrm{~mm}$ which has good inter-granular corrosion resistance which increase the life span pressure vessels and automobile components. Superior fracture toughness reduces the crack initiation and crack growth under high pressure. These two factors enhances the maximum pressure withstandability, apart from this PulsedTIG welding process is used for welding which reduces the heat affected zone by welding the material by alternate melting and cooling which forms a good grain boundary layered by chromium with maximum strength. And this material does not require post process annealing for hardening which is used to increase the strength of the material. Quality of weld is based on the protrusion of weld from face to root and good quality weld can be obtained by optimizing the process parameters like current, voltage, stand-off distance, pulse on time, pulse off time, weld speed to improve weld quality. In this paper, experimental investigation detail of various process parameters to obtain good quality weld is discussed. The Taguchi design of experiments is a powerful method used to achieve high quality in lesser no of experiments. It provides better settings as compared to traditional experimental designs which are time consuming due to a large number of experiments and most of the time not feasible. The Taguchi method reduces the sensitivity of quality characteristics to various unknown noise factors.

\section{LITERATURE SURVEY}

Balasubramaniyan et al.,[1] discussed about the Effect of microstructure on impact toughness of pulsed current GTA welded $\alpha-\beta$ titanium alloy, the pulsed current has been found to be beneficial primarily due to its advantages over the conventional continuous current process. Aniruth et al.,[2] discussed about the study on laser cleaning and pulsed gas tungsten arc welding of $\mathrm{Ti}-3 \mathrm{Al}-2.5 \mathrm{~V}$ alloy tubes, Welding of laser-cleaned samples show excellent weld quality. G.Lothongkum et al[4] discussed the Study on the effects of pulsed TIG welding parameters on delta-ferrite content, shape factor and bead quality in orbital welding of AISI 316L stainless steel plate, because of the high nitrogen content of the cover gas and lowest pulse currents compared to all other welding positions. Radiography showed 
acceptable weld beads free of porosity. Juang et al.[8] discussed about Process parameter selection for optimizing the weld pool geometry in the tungsten inert gas welding of stainless steel the selection of process parameters for obtaining an optimal weld pool geometry in the tungsten inert gas (TIG) welding of stainless steel the front height, front width, back height and back width of the weld pool. Karafi et al.[12] discussed about Study on automatic control of arc gap in robotic TIG welding. This paper presents a method for automatic control of arc length in tungsten inert gas (TIG) welding process using the arc voltage. Zhang et al. [16] discussed about the Laser cladding of Colmonoy powder on AISI316L austenitic stainless steel in which he proves that austenitic stainless steel has good inter-granular corrosion resistance.

From the above literature reviews, it has been observed that there is need for improving quality of the thin sheet welding for various applications like pressure vessels, automobile etc. These literatures provide that the thermal conductivity of stainless steel is very less and normal welding process increases heat affected zone hence Pulsed-TIG welding process is used to Increase the strength of pressure vessel by reducing the heat affected zone. Quality of weld depend on the protrusion of weld from face to root hence Optimizing the process parameters like current, voltage, pulse on time, pulse off time, weld speed is required to improve weld quality an opportunity to do the work on Pulsed TIG to develop the strength and quality of the weldment and this work on stainless steel 304L was not reviewed in most of the literatures available till now.

\section{EXPERIMENTAL PROCEDURE:}

\subsection{Welding Parameter Selection}

In this paper FRONIUS welding machine (Magic Wave/Trans TIG) is used for experimentation. The bead on trials are made in $2 \mathrm{~mm}$ Stainless Steel plate. The machining parameters were selected on the basis of various trial runs by checking their effect on depth of penetration. Initially the parameters considered for experimentation were speed, current, stand-off distance, frequency and gas flow. And after conducting few trials it was found that the frequency and gas flow does not influence the depth of penetration, width of weld bead and area of the weld profile hence both the parameters are maintained constant. The trials were taken for the current range of $75 \mathrm{~A}$ to $125 \mathrm{~A}$, speed ranging from $125 \mathrm{~mm} / \mathrm{min}$ to $375 \mathrm{~mm} / \mathrm{min}$ and standoff distance / Arc length ranging from $2 \mathrm{~mm}$ to $4 \mathrm{~mm}$. The initial machining parameters used for Welding 304L Stainless Steel were as follows: current-75 A, Speed $125 \mathrm{~mm} / \mathrm{min}$, Standoff Distance $2 \mathrm{~mm}$, were frequency and gas flow were maintained constant as $3 \mathrm{~Hz}$ and 10 liter/min. The welding parameters and levels are shown in Table 1.

\subsubsection{Welding Performance Evaluation}

The Welding performances considered in this paper is Depth of Penetration. Struers Welding Expert System is used for measuring depth of penetration, width of weld bead and Shape/Area of the weld.

$$
\text { Depth of Penetration= } n \text { Alfg (1) }
$$

Where $\mathrm{n}$ is weld speed in $\mathrm{mm} / \mathrm{min}$, $\mathrm{A}$ is the Current in Ampere (A), 1 is stand-off distance in $\mathrm{mm}, \mathrm{f}$ is the frequency in $\mathrm{Hz}$ and $\mathrm{g}$ is the gas flow in litre/minute $(1 / \mathrm{m})$.

Constant Parameters:

Frequency: $3 \mathrm{~Hz}$

Gas flow : 10 litre/minute

Table: 1 Welding parameters and levels

\begin{tabular}{|l|l|l|l|l|}
\hline Symbol & Parameters & Level1 & Level2 & Level3 \\
\hline A & Speed (mm/min) & 125 & 250 & 375 \\
\hline B & $\begin{array}{l}\text { Stand-off Distance } \\
(\mathrm{mm})\end{array}$ & 2 & 3 & 4 \\
\hline C & Current (Amps) & 75 & 100 & 125 \\
\hline
\end{tabular}

\subsubsection{Material Specification}

A thin sheet of 304L Stainless Steel was used for experimentation with length $150 \mathrm{~mm}$, width $40 \mathrm{~mm}$ and thickness $1.6 \mathrm{~mm}$. The chemical composition and mechanical properties of the material are shown in the Table 2 and Table 3.

Table: 2 Chemical Composition of 304L Stainless Steel

\begin{tabular}{|l|l|}
\hline Chemicals & \% of Composition \\
\hline Carbon & 0.03 \\
\hline Manganese & 2.00 \\
\hline Phosphorus & 0.045 \\
\hline Sulphur & 0.03 \\
\hline Silica & 0.75 \\
\hline Chromium & $18-20$ \\
\hline Nickel & $8-12$ \\
\hline Nitrogen & 0.10 \\
\hline Iron & $67-71$ \\
\hline
\end{tabular}

Table: 3 Mechanical properties of 304L Stainless Steel

\begin{tabular}{|l|l|}
\hline Tensile Strength & $564 \mathrm{MPa}$ \\
\hline Yield Strength & $241 \mathrm{MPa}$ \\
\hline Hardness & $\mathrm{B} 80 \mathrm{HBN}$ \\
\hline Melting Point & $1400-1450{ }^{\circ} \mathrm{C}$ \\
\hline Density & $8 \mathrm{~g} / \mathrm{cm}^{3}$ \\
\hline
\end{tabular}

\subsubsection{Experimental Process}

Experiment is carried out FRONIUS (Magic Wave/Trans TIG) welding machine which has the different modules for TIG, Pulsed TIG and Plasma Arc and this project is carried out with Pulsed-TIG welding module in Stainless steel specimens with dimensions $150 * 30 * 1.6 \mathrm{~mm}^{3}$ were cut and milled and edge preparation is made by using wire EDM. 


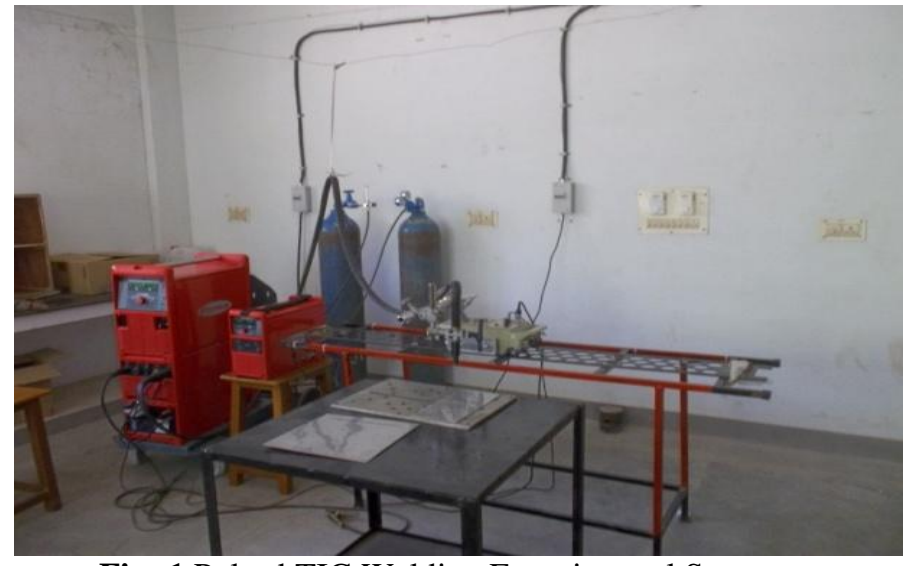

Fig: 1 Pulsed TIG Welding Experimental Setup

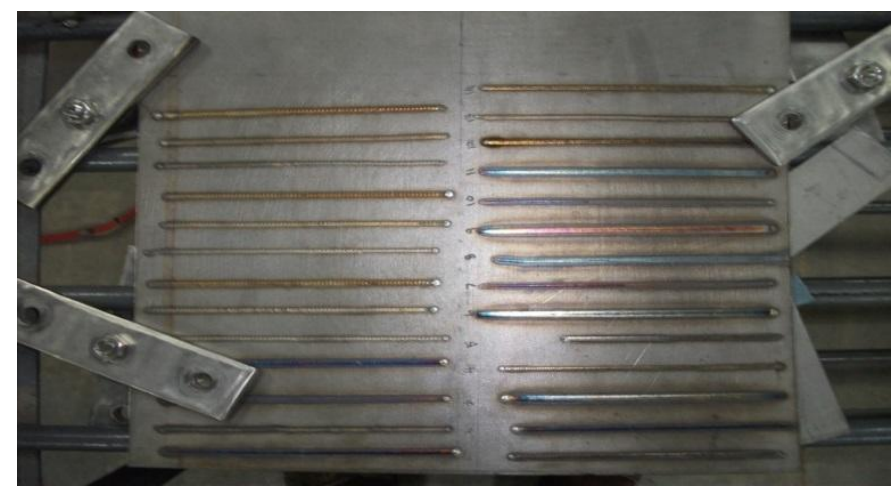

Fig: 2 Trials based on L27 Orthogonal Array

Figure 2 represents the bead on trials based on the orthogonal array. Before conducting trials surfaces of the samples were cleaned using acetone and were placed on the stainless steel fixture and bead on plate trials were carried out in order to optimize the depth of penetration suitable for $1.6 \mathrm{~mm}$ plate based on the Taguchi model integrated for obtaining L27 Orthogonal array with the parameters mentioned below and with that trials are carried out in $2 \mathrm{~mm}$ plate and cross sectional profile is cut using wire EDM.

Then followed by Polishing process which includes emery polishing, aluminium powder polishing and diamond paste polishing in Metco Polishing Machine. After polishing the work piece etching process is carried out for macro structure and micro structural analysis by means of combination of Etchents like Aquagiria and Nital for 10 seconds and 30 seconds respectively for good weld bead profile and the parameters like depth of penetration, width of the weld bead and area of the weld bead geometry are measured using Strues Welding Expert System. Then for validation of strength of weld the optimized parameter is used for welding of $1.6 \mathrm{~mm}$ sheets then tensile test is carried out by cutting the weld profile in Dog bone shape with dimension as mentioned on ASTM standard E8, and bend test is carried out by cutting the weld profile with the dimension as mentioned on ASTM standard E190, both the testing is carried out in Tinius olsen UTM machine.

\section{RESULTS AND DISCUSSIONS}

The trials are made on the $2 \mathrm{~mm}$ plate designed by Taguchi model L27 Orthogonal array with 3 factor 3 level design and corresponding depth of penetration for each trial is calculated by means of Welding Expert system. The results of L27 array is as shown in the table 4:

Table: 4 Experimental layout using L27 array and responses

\begin{tabular}{|c|c|c|c|c|c|c|}
\hline $\begin{array}{l}\mathrm{S} \\
\mathrm{N} \\
\mathrm{o}\end{array}$ & $\begin{array}{l}\text { Speed } \\
(\mathrm{mm} / \mathrm{mi} \\
\mathrm{n})\end{array}$ & $\begin{array}{l}\text { Stand } \\
\text { Off } \\
\text { Distan } \\
\text { ce } \\
(\mathrm{mm}) \\
\end{array}$ & $\begin{array}{l}\text { Curre } \\
\text { nt } \\
\text { (amp } \\
\text { s) }\end{array}$ & $\begin{array}{l}\text { Volta } \\
\text { ge } \\
\text { (volts) }\end{array}$ & $\begin{array}{l}\text { Depth } \\
\text { of } \\
\text { Penetra } \\
\text { tion } \\
(\mathrm{mm}) \\
\end{array}$ & $\begin{array}{l}\text { Widt } \\
\mathrm{h} \text { of } \\
\text { Weld } \\
(\mathrm{mm})\end{array}$ \\
\hline 1 & 125 & 2 & 75 & 8.6 & 1.159 & 2.29 \\
\hline 2 & 125 & 2 & 100 & 8.4 & 1.393 & 3.366 \\
\hline 3 & 125 & 2 & 125 & 8.3 & 1.612 & $\begin{array}{l}4 . \\
152\end{array}$ \\
\hline 4 & 125 & 3 & 75 & 10.8 & 0.7879 & $\begin{array}{l}2.268 \\
6\end{array}$ \\
\hline 5 & 125 & 3 & 100 & 10.5 & 1.0512 & $\begin{array}{l}2.109 \\
6\end{array}$ \\
\hline 6 & 125 & 3 & 125 & 9.7 & 1.573 & 4.017 \\
\hline 7 & 125 & 4 & 75 & 10.8 & 0.8036 & $\begin{array}{l}2.372 \\
6\end{array}$ \\
\hline 8 & 125 & 4 & 100 & 11.7 & 0.978 & $\begin{array}{l}2.452 \\
3\end{array}$ \\
\hline 9 & 125 & 4 & 125 & 11.7 & 1.4173 & $\begin{array}{l}3.779 \\
5\end{array}$ \\
\hline 10 & 250 & 2 & 75 & 8.4 & 1.063 & 2.104 \\
\hline 11 & 250 & 2 & 100 & 10.7 & 1.325 & 2.415 \\
\hline 12 & 250 & 2 & 125 & 10.1 & 1.4906 & $\begin{array}{l}3.009 \\
4\end{array}$ \\
\hline 13 & 250 & 3 & 75 & 11 & 0.6387 & $\begin{array}{l}1.431 \\
3\end{array}$ \\
\hline 14 & 250 & 3 & 100 & 10.2 & 1.073 & 2.181 \\
\hline 15 & 250 & 3 & 125 & 10 & 1.2922 & $\begin{array}{l}3.002 \\
5\end{array}$ \\
\hline 16 & 250 & 4 & 75 & 11.3 & 0.6059 & $\begin{array}{l}1.515 \\
4\end{array}$ \\
\hline 17 & 250 & 4 & 100 & 11.3 & 0.6705 & $\begin{array}{l}1.762 \\
9\end{array}$ \\
\hline 18 & 250 & 4 & 125 & 11.9 & 0.9172 & $\begin{array}{l}2.561 \\
2\end{array}$ \\
\hline 19 & 375 & 2 & 75 & 11 & 1.163 & 2.104 \\
\hline 20 & 375 & 2 & 100 & 10.8 & 0.6532 & $\begin{array}{l}1.335 \\
7\end{array}$ \\
\hline 21 & 375 & 2 & 125 & 10.6 & 0.9735 & $\begin{array}{l}2.077 \\
4\end{array}$ \\
\hline 22 & 375 & 3 & 75 & 10.9 & 0.649 & $\begin{array}{l}1.160 \\
1\end{array}$ \\
\hline 23 & 375 & 3 & 100 & 10.4 & 0.7441 & $\begin{array}{l}1.970 \\
9\end{array}$ \\
\hline 24 & 375 & 3 & 125 & 11.3 & 1.188 & $\begin{array}{l}2.293 \\
7\end{array}$ \\
\hline 25 & 375 & 4 & 75 & 11 & 0.6518 & $\begin{array}{l}1.282 \\
3\end{array}$ \\
\hline 26 & 375 & 4 & 100 & 10.7 & 0.6931 & $\begin{array}{l}1.824 \\
5\end{array}$ \\
\hline
\end{tabular}




\begin{tabular}{l|l|l|l|l|l|l|}
27 & 375 & 4 & 125 & 10.8 & 0.9344 & $\begin{array}{l}2.109 \\
1\end{array}$ \\
\hline
\end{tabular}

\subsection{Signal to Noise Ratio}

The $\mathrm{S} / \mathrm{N}$ ratio is the ratio of size of signal factor effect to the size of error factor effect . The $\mathrm{S} / \mathrm{N}$ ratio consolidates several repeated output responses into a single value which reflects the amount of variation present . The $\mathrm{S} / \mathrm{N}$ ratio measures the sensitivity of quality characteristic to external noise factor which is not under control. The highest $\mathrm{S} / \mathrm{N}$ ratio implies the least sensitivity of output response to noise factors. On the basis of characteristic three $\mathrm{S} / \mathrm{N}$ ratios are available namely lower the better, higher the better and nominal the better. In this paper higher-the-better is used for maximizing both depth of penetration and width of the weld bead.

The higher-the-better performance characteristic is expressed

$$
\mathrm{S} / \mathrm{N}_{\mathrm{HB}}=-10 \log \left\{\left(1 / \mathrm{y}_{1}{ }^{2}+1 / \mathrm{y}_{2}{ }^{2} \ldots 1 / \mathrm{y}_{\mathrm{n}}{ }^{2}\right) / \mathrm{n}\right\} \text { (1) }
$$

Where $\mathrm{n}$ is the number of repetition of output response in the same trial and $y$ is the response.

Table: $5 \mathrm{~S} / \mathrm{N}$ ratios of responses

\begin{tabular}{|c|c|c|}
\hline S.No & $\begin{array}{l}\text { Depth of } \\
\text { Penetration (mm) }\end{array}$ & S/N Ratio \\
\hline 1 & 1.159 & 1.281668719 \\
\hline 2 & 1.393 & 2.879022328 \\
\hline 3 & 1.612 & 4.147300749 \\
\hline 4 & 0.7879 & -2.07057799 \\
\hline 5 & 1.0512 & 0.433707044 \\
\hline 6 & 1.573 & 3.934574452 \\
\hline 7 & 0.8036 & -1.899201438 \\
\hline 8 & 0.978 & -0.193222904 \\
\hline 9 & 1.4173 & 3.029235742 \\
\hline 10 & 1.063 & 0.53066529 \\
\hline 11 & 1.325 & 2.444317565 \\
\hline 12 & 1.4906 & 3.467222338 \\
\hline 13 & 0.6387 & -3.894061677 \\
\hline 14 & 1.073 & 0.611994439 \\
\hline 15 & 1.2922 & 2.226594734 \\
\hline 16 & 0.6059 & -4.35198095 \\
\hline 17 & 0.6705 & -3.472024356 \\
\hline 18 & 0.9172 & -0.750719079 \\
\hline 19 & 1.163 & 1.311594295 \\
\hline 20 & 0.6532 & -3.699076479 \\
\hline 21 & 0.9735 & -0.233280883 \\
\hline 22 & 0.649 & -3.755106064 \\
\hline 23 & 0.7441 & -2.567373909 \\
\hline 24 & 1.188 & 1.496328813 \\
\hline 25 & 0.6518 & -3.717712877 \\
\hline 26 & 0.6931 & -3.184082023 \\
\hline 27 & 0.9344 & -0.589343405 \\
\hline
\end{tabular}

This table 5 shows the result obtained from the orthogonal array and signal-to-noise ratio. Here there is a need to increase the depth of penetration, hence the maximum is the best is selected and the main effects for the Signal to noise ratio is plotted in the following graph.

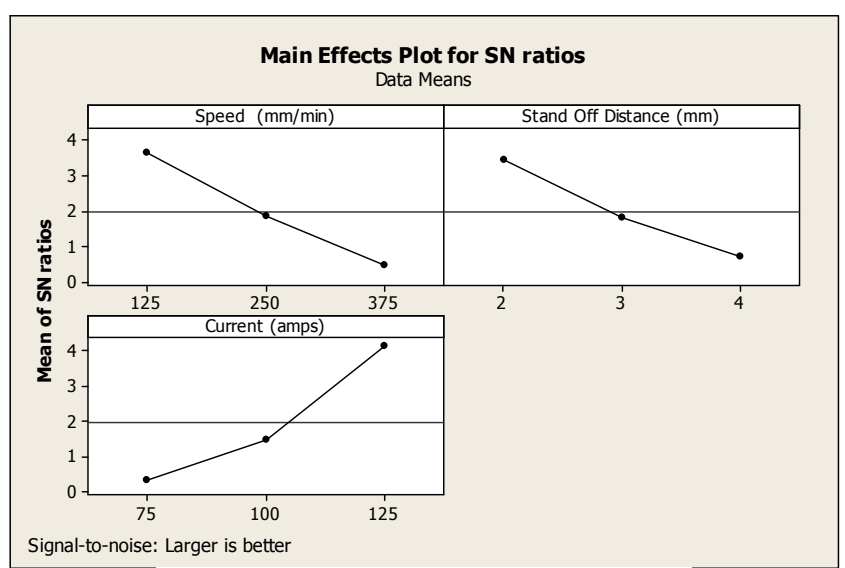

Fig: 4 Main Effect Plot for S/N Ratios

\subsection{Confirmation Test}

Further confirmation is required as weld quality changes based on the environmental change so by making standoff distance constant further proceed with experimentation by using L9 Orthogonal array.

Table: 6 Parameter for L9 Orthogonal array

\begin{tabular}{|l|l|l|l|l|}
\hline Symbol & Parameters & Level1 & Level2 & Level3 \\
\hline A & Speed (mm/min) & 100 & 125 & 150 \\
\hline B & Current (A) & 100 & 125 & 150 \\
\hline
\end{tabular}

From optimization technique we found that maximum current with minimum speed increases the depth of penetration hence we modified our input accordingly and made 9 more confirmation runs.

Table: 7 Confirmation test:

\begin{tabular}{|l|l|l|l|l|l|}
\hline S No. & $\begin{array}{l}\text { Speed } \\
(\mathrm{mm} / \mathrm{min})\end{array}$ & $\begin{array}{l}\text { Current } \\
(\mathrm{amps})\end{array}$ & $\begin{array}{l}\text { Voltage } \\
(\text { volts })\end{array}$ & $\begin{array}{l}\text { Depth of } \\
\text { Penetration } \\
(\mathrm{mm})\end{array}$ & $\begin{array}{l}\text { Width } \\
\text { of } \\
\text { Weld } \\
(\mathrm{mm})\end{array}$ \\
\hline 1 & 100 & 100 & 10 & 1.523 & 4.038 \\
\hline 2 & 100 & 125 & 10.1 & 1.654 & 4.996 \\
\hline 3 & 100 & 150 & 10.4 & 1.959 & 5.629 \\
\hline 4 & 125 & 100 & 9.4 & 1.412 & 3.73 \\
\hline 5 & 125 & 125 & 9.1 & $\mathbf{1 . 6 0 7}$ & 4.667 \\
\hline 6 & 125 & 150 & 9.7 & 1.805 & 6.392 \\
\hline 7 & 150 & 100 & 9.3 & 1.432 & 3.719 \\
\hline 8 & 150 & 125 & 9.5 & 1.723 & 4.557 \\
\hline 9 & 150 & 150 & 9.4 & 1.846 & 5.417 \\
\hline
\end{tabular}

From the confirmation run it is found that speed 125 $\mathrm{mm} / \mathrm{min}$ and current $125 \mathrm{~A}$ has depth of penetration closer to $1.6 \mathrm{~mm}$. 


\subsection{Validation by Strength Analysis}

Hence with optimized parameter butt joining of $1.6 \mathrm{~mm}$ plate is done then based on ASTM standard weld specimens are cut to standard for tensile and bend test and test is done in Tinson UTM machine to validate the strength of the weld joint.

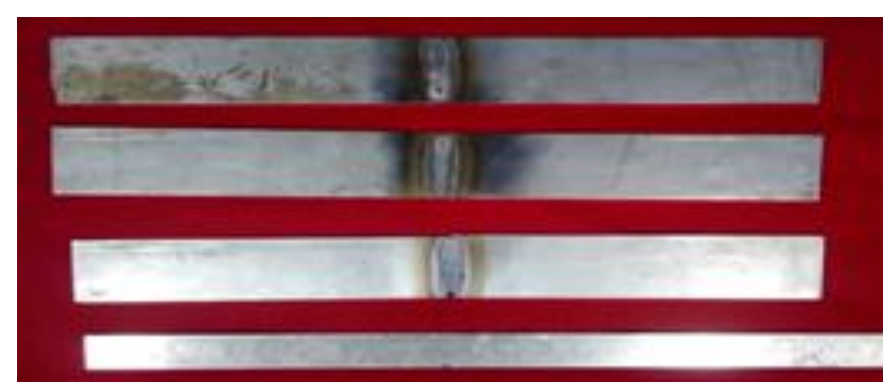

Fig: 5 Butt Joint of 1.6mm Plate

\subsubsection{Tensile Test}

Based on ASTM standard E8/E8M tensile specimen is cut using Wire EDM for testing.

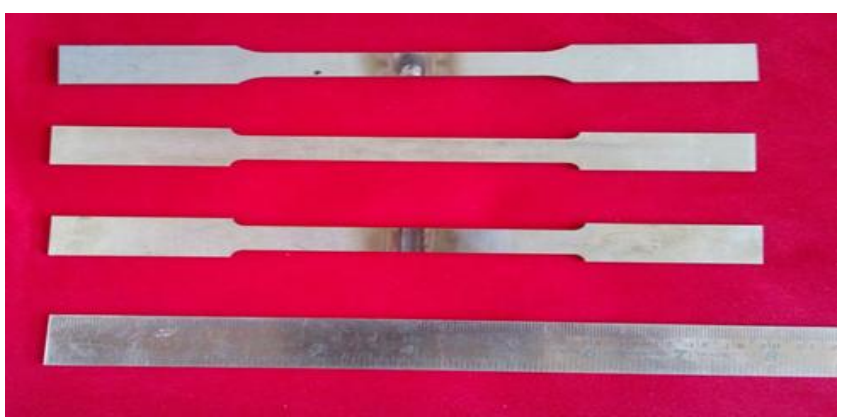

Fig: 6 Tensile Test Specimen before test

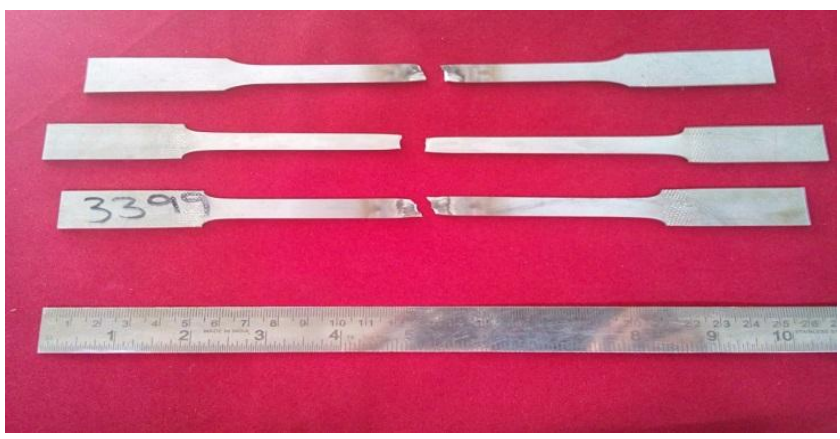

Fig: 7 Tensile Test Specimen after test

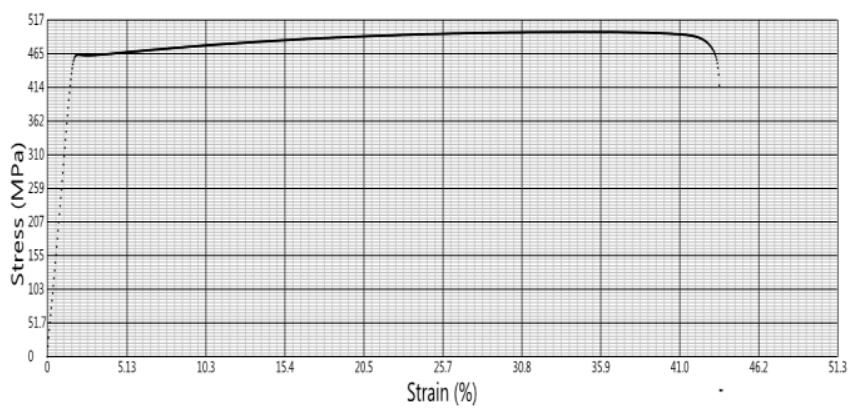

Fig: 8 Parent Metal Tensile test Graph

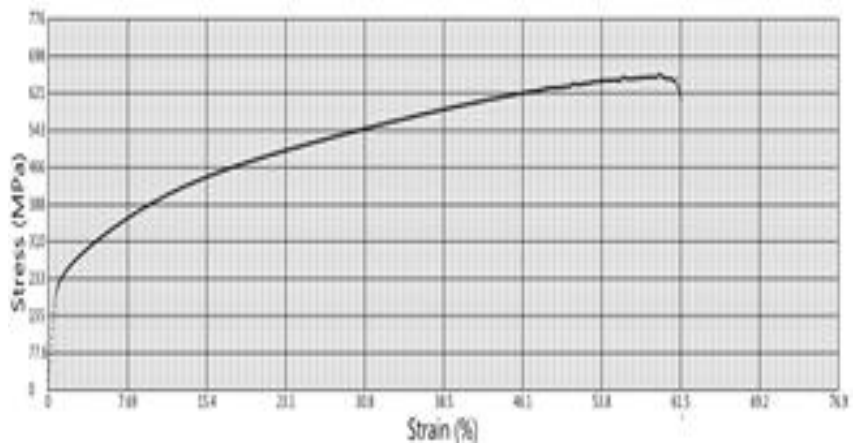

Fig: 9 Weld Joint Tensile test Graph

Table: 9 Tensile test result of Parent metal and Weld Joint

\begin{tabular}{|l|l|l|l|l|l|l|}
\hline $\begin{array}{l}\text { Wor } \\
\mathrm{k} \\
\text { Piec } \\
\mathrm{e}\end{array}$ & $\begin{array}{l}\text { Wid } \\
\text { th } \\
\mathrm{mm}\end{array}$ & $\begin{array}{l}\text { Thickn } \\
\text { ess } \\
\mathrm{Mm}\end{array}$ & $\begin{array}{l}\text { Ultim } \\
\text { ate } \\
\text { Force } \\
\mathrm{N}\end{array}$ & $\begin{array}{l}\text { Ultim } \\
\text { ate } \\
\text { Stress } \\
\mathrm{MPa}\end{array}$ & $\begin{array}{l}\text { Break } \\
\text { Dista } \\
\text { nce } \\
\mathrm{mm}\end{array}$ & $\begin{array}{l}\text { Total } \\
\text { Elongat } \\
\text { ion } \\
\%\end{array}$ \\
\hline $\begin{array}{l}\text { Pare } \\
\mathrm{nt} \\
\text { Met } \\
\text { al }\end{array}$ & 12.5 & 1.6 & 9980 & 499 & 49.46 & 49.46 \\
\hline $\begin{array}{l}\text { Wel } \\
\mathrm{d} \\
\text { Met } \\
\text { al }\end{array}$ & 12.5 & 1.6 & 13200 & 659 & 61.6 & 61.6 \\
\hline $\begin{array}{l}\text { Res } \\
\text { ult }\end{array}$ & - & - & +3220 & +160 & +12.1 & +12.14 \\
\hline
\end{tabular}

From table 9 results the weld specimen has $3220 \mathrm{~N}$ force with standability , $160 \mathrm{MPa}$ increase in Ultimate stress and $12.14 \mathrm{~mm}$ extended elongation than the parent metal.

\subsubsection{Bend Test}

Based on ASTM standard E190/E192 bend test specimens are cut using Wire EDM.

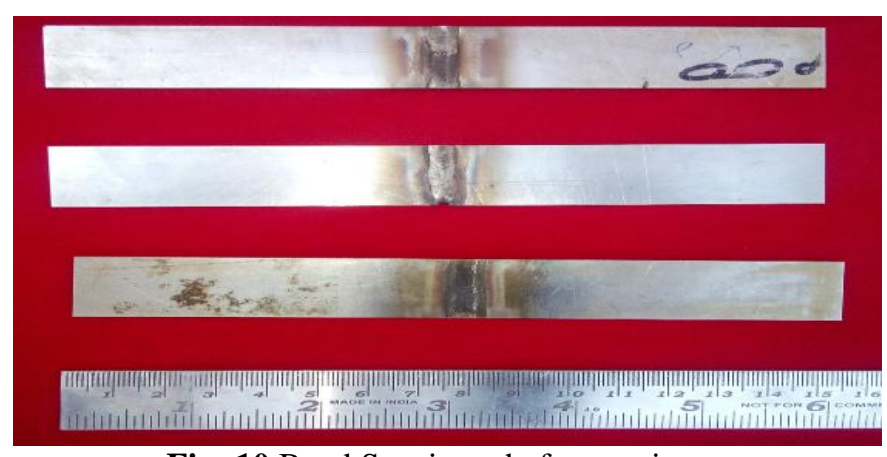

Fig: 10 Bend Specimen before testing 


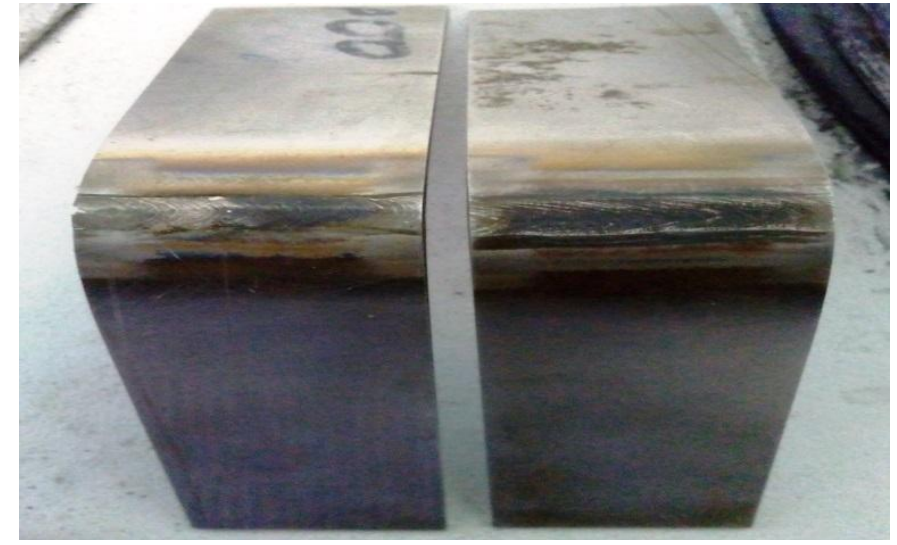

Fig: 11 Bend Specimen after testing

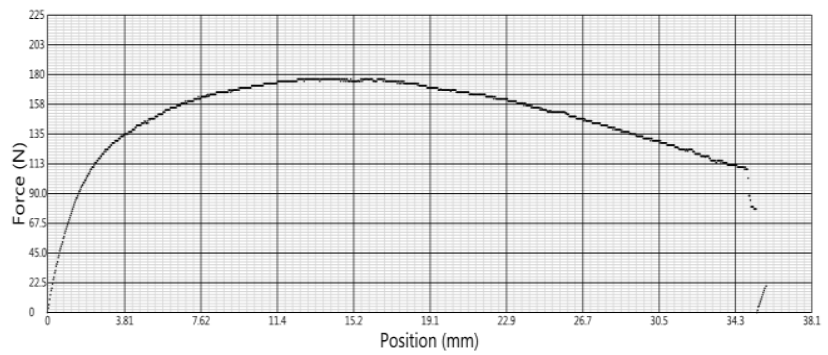

Fig: 14 Bend test Graph on face side of weld

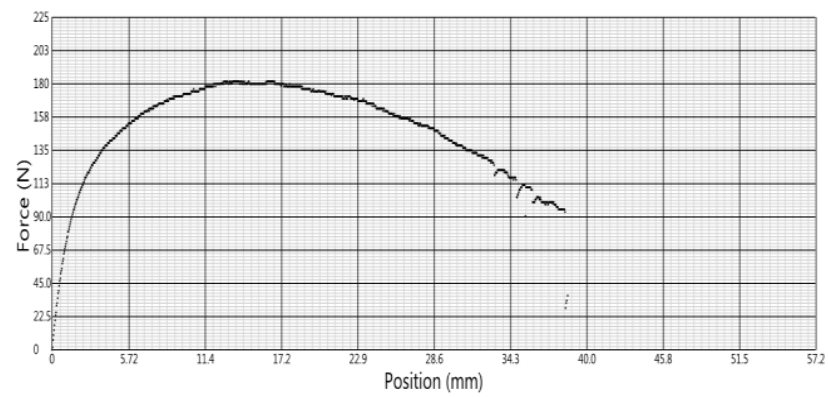

Fig: 15 Bend test Graph on root side of weld

Table: 11 Bend test result on root side of weld

\begin{tabular}{|l|l|l|l|l|l|l|}
\hline $\begin{array}{l}\text { Wor } \\
\mathrm{k} \\
\text { Piec } \\
\mathrm{e}\end{array}$ & $\begin{array}{l}\text { Wid } \\
\text { th } \\
\mathrm{mm}\end{array}$ & $\begin{array}{l}\text { Thickn } \\
\text { ess } \\
\mathrm{mm}\end{array}$ & $\begin{array}{l}\text { Are } \\
\mathrm{a} \\
\mathrm{m} \\
\mathrm{m}^{2}\end{array}$ & $\begin{array}{l}\text { Ultim } \\
\text { ate } \\
\text { Force } \\
\mathrm{N}\end{array}$ & $\begin{array}{l}\text { Ultim } \\
\text { ate } \\
\text { Stress } \\
\text { MPa }\end{array}$ & $\begin{array}{l}\text { Observat } \\
\text { ion }\end{array}$ \\
\hline $\begin{array}{l}\text { Fac } \\
\text { Side }\end{array}$ & $\begin{array}{l}25.4 \\
0\end{array}$ & 1.60 & $\begin{array}{l}40 . \\
6\end{array}$ & 181.67 & 385.55 & $\begin{array}{l}\text { No } \\
\text { opening } \\
\text { or Crack } \\
\text { formatio } \\
\text { n }\end{array}$ \\
\hline $\begin{array}{l}\text { Roo } \\
\text { Side }\end{array}$ & $\begin{array}{l}25.4 \\
\text { Side }\end{array}$ & 1.60 & 40. & 176.67 & 489.05 & $\begin{array}{l}\text { No } \\
\text { opening } \\
\text { or Crack } \\
\text { formatio } \\
\text { n }\end{array}$ \\
\hline
\end{tabular}

From table 11 results it is clear that both face and root side of weld does not infer any defect which clear that the optimal parameter gives a good quality weld from face to root of the weld joint.

\section{CONCLUSIONS}

This paper has presented the optimization of process parameters of welding of $1.6 \mathrm{~mm}$ thin sheets of $304 \mathrm{~L}$ Stainless Steel material with multiple performance characteristics. . Based on experimental results and confirmation tests the following conclusions can be drawn.

The optimum values obtained from the selected factors for welding of $1.6 \mathrm{~mm}$ plate are Speed $125 \mathrm{~mm} / \mathrm{min}$, Current $125 \mathrm{~A}$, Stand-off $2 \mathrm{~mm}$, Frequency $3 \mathrm{~Hz}$, Gas flow 10 litre/min.

The most important parameters affecting the responses have been identified as speed and current.

$>\quad$ Validation of weld strength is made by tensile and bend test. Also found that there is good improvement in tensile strength after optimizing while comparing with parent metal and bend test result in no opening or crack formation. Hence a good quality weld is obtained from face to root.

$>\quad$ By this study, the optimized process parameters would definitely solve the problems of corrosion and fatigue faced by the material, by improving the weld quality.

$>\quad$ At the same time, it increases the strength of the weld with minimum heat affected zone.

\section{ACKNOWLEDGEMENTS}

Authors gratefully acknowledge the support of the staffs and research scholars of Department of Mechanical Engineering, National Institute of Technology, Trichy for providing Experimental facilities and technical guidance during different stages of the project work. Authors also wish to thank staffs in Department of Production Engineering, PSG College of Technology, Coimbatore for their support during various phases for this work.

\section{REFERENCES}

[1] M. Balasubramanian, V. Jayabalan and V. Balasubramanian.," Effect of microstructure on impact toughness of pulsed current GTA welded $\alpha-\beta$ titanium alloy", Materials Letters, vol.62, pp. 1102$1106,2008$.

[2] Aniruddha Kumar., Mark Sapp, Jay Vincelli and Mool C. Gupta.," A study on laser cleaning and pulsed gas tungsten arc welding of $\mathrm{Ti}-3 \mathrm{Al}-2.5 \mathrm{~V}$ alloy tubes", Journal of Materials Processing Technology,vol.210, pp. 64-71,2010.

[3] Chun-Ming Lin , Hsien-Lung Tsai , Chun-Der Cheng and Cheng Yang.," Effect of repeated weld-repairs on microstructure, texture, impact properties and corrosion properties of AISI 304L stainless steel", Engineering Failure Analysis vol.21 pp. 9-20, 2012.

[4] G. Lothongkum, E. Viyanit and P. Bhandhubanyong," Study on the effects of pulsed TIG welding parameters on delta-ferrite content, shape factor and bead quality in orbital welding of AISI 316L stainless steel plate", Journal of Materials Processing Technology Vol.110 pp. 233-238, 2000. 
[5] G. Casalino , F.W. Panella. "Microstructural analysis of AISI 304 bars welded with high speed pulsed discharges". Journal of Materials Processing Technology, vol.191, pp. 149-152, 2007 Kumar A., and Sundarrajan S., "Optimization of pulsed TIG welding process parameters on mechanical properties of AA 5456 Aluminum alloy weldments", Journal of Materials and Design, Vol. 30, pp. 1288-1297, 2009.

[6] Wang Q., Sun D.L., Na Y., Zhou Y., Han X.L. and Wang J., "Effects of TIG Welding Parameters on Morphology and Mechanical Properties of Welded Joint of Ni-base Super alloy", Journal of Procedia Engineering, Vol. 10, pp. 37-41, 2011.

[7] Juang S.C., and Tarng Y.S., "Process parameter selection for optimizing the weld pool geometry in the tungsten inert gas welding of stainless steel", Journal of Materials Processing Technology, Vol. 122, pp. 33-37, 2002.

[8] Dongjie Li., Shanping Lu., Wenchao Dong., Dianzhong Li., Yiyi Li., "Study of the law between the weld pool shape variations with the welding parameters under two TIG processes", Journal of Materials Processing Technology, Vol. 212, pp. 128136, 2012

[9] Gang Wang T., Warren Liao.," Automatic identification of different types of welding defects in radiographic images", Journal of NDT\&E International, Vol.35, pp. 519-528, 2002.

[10] Lixing Huo., Dongpo Wang., Yufeng Zhang.," Investigation of the fatigue behaviour of the welded joints treated by TIG dressing and ultrasonic peening under variable-amplitude load", International journal of Fatigue, Vol.27, pp 95-101, 2005.

[11] Mohammad Reza Karafi ., Ramin Narimani ., Yousef Hojjat ., Mojtaba Gheybi .," Study on automatic control of arc gap in robotic TIG welding", Journal of Advanced Manufacturing Technology, Vol.50, pp 953-960, 2010.

[12] Webster P.J., Ananthaviravakumar N., Hughes D.J., Mills G., Preston R.V., Shercliff H.R., Withers3 P.J.," Measurement and modelling of residual stresses in a TIG weld", the journal of applied physics, vol. 74, pp 421-423, 2002.

[13] Bull C.E., Stacey K.A., Calcraft R.,” On line weld monitoring using ultrasonic", Journal of nondestructive Testing, Vol 35 (2), pp 57-64, 1993.

[14] AhmetDurgutlu.,"Experimental investigation of the effect of hydrogen in argon as a shielding gas on TIG welding of austenitic stainless steel", Journal of materials and Design, Vol 25, pp 19-23,2004.

[15] O. K. Chopra, B. Alexandreanu, E. E. Gruber, R. S. Daum, W. J. Shack "Crack Growth Rates of Irradiated Austenitic Stainless Steel Weld Heat Affected Zone in BWR Environments" U.S. Nuclear Regulatory Commission DC 20555-0001, 2006.

\section{BIOGRAPHIES:}

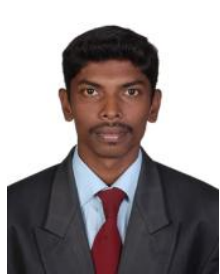

Mr.R.Dinesh Kumar is a PG Student currently doing his Final Year MEProduction Engineering inSG in PSG College of Technology, Coimbatore. He has undergone an internship project at NIT Trichy. He did did his BE - Mechanical Engineering in Saranathan College of Engineering and he is very passionate towards sports, won many medals in zonal and inter-zonal tournament in UG \& PG.

E - Mail: dineshrd453@gmail.com; Mob:+919865138376

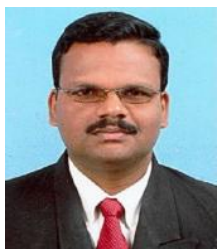

Dr.S.Elangovan is working as Associate Professor in Department of Production Engineering, PSG College of Technology Coimbatore. He has 4 years of Industrial Experience and 15 years of Academic Experience. He has published 5 Inter National Journals, attend 5 International Conference and 17 National Conference. Not limiting with it he has organized several Workshop, FDP and been a keynote speaker. And he is guiding one Research Scholar.

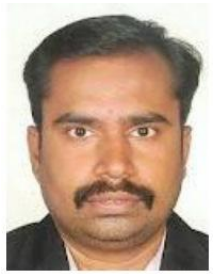

Dr.N.Siva Shanmugam is working as Assistant Professor in Department of Mechanical Engineering, National Institute of Technology Tiruchirappalli. He has 10 years of Academic Experience. He has published 16 Inter National Journals, attend 8 International Conference. Beyond this he has delivered 12 Guess lectures in various Engineering Colleges. He is reviewer for 3 Inter National Journals and 4 books. At present he is guiding 3 Research Scholars and Working with several Sponsored Projects. 